\title{
INVESTIGATION OF HELICOBACTER PYLORI VIRULENCE GENOTYPE IN GASTRIC BIOPSIES BY POLYMERASE CHAIN REACTION
}

\author{
RABAB OMRAN ${ }^{1 *}$, HAIDER ALI M AL-NAJI ${ }^{1}$, ALI AL-SHERIFY ${ }^{2}$ \\ ${ }^{1}$ Department of Biology, College of Science, University of Babylon, Iraq. ${ }^{2}$ Branch of Internal Medicine, College of Medicine, \\ University of Babylon, Iraq. Email: omranaljelawi@gmail.com/sci.rabab.omran@uobabylon.edu.iq
}

Received: 30 June 2016 Revised and Accepted: 05 July 2016

\section{ABSTRACT}

Objectives: Helicobacter pylori infections have been associated with the genetic diversity of their virulence factors; the virulence genotypes are valuable as a molecular marker in the diagnosis of patients with bacterial infections. Our main objective was to analyze the frequency and allelic genotype of vacuolating cytotoxin $\mathrm{A}(\mathrm{vacA})$ and cytotoxin-associated gene $\mathrm{A}(\mathrm{cag} A)$ as well as investigate other virulence genes like outer inflammatory protein A gene (oipA) and a gene contact with the epithelium (iceA) of H. pylori.

Methods: A total of 75 patients with gastritis and peptic ulcer diseases (PUDs) were selected to investigate $H$. pylori infections. 75 antrum biopsies were collected from these patients, and then genomic DNA was extracted from biopsies using the genomic DNA kit. Subsequently, the virulence genes of $H$. pylori were amplified using specific primers for vacA, cagA, cagE, iceA, and oipA by polymerase chain reaction (PCR).

Results: A high prevalence of genes cagA (28.6\%), vacAs1bm2 (44.68\%), iceA2 (30.6\%), and oipA (42.9\%) was found, while vacA s2m1 and iceA1 genotypes was not found in our study. There was a significant correlation between the presence of $\operatorname{cag} A$ and $\operatorname{cag} E$ genotypes ( $\mathrm{p}=0.02$ ), suggesting that these two genes almost used together as a cagPAI integrity marker and the predominant cagA EPIYA motif was ABC ( $\sim 650 \mathrm{bp})$ belong to Western cagA strains. The presence of the $c a g A^{+}$and $v a c A^{+}$genes was significantly associated with peptic ulceration $(\mathrm{p} \leq 0.001$ at a level 0.01 and $\mathrm{p} \leq 0.044$ at a level 0.05 , respectively), whereas different iceA2 genotype was no statistically significant with clinical outcome. Patients with PUD more likely to have an oipA gene (61.9\%) than those with gastritis (38.1\%), $\mathrm{p} \leq 0.037$, also the presence oipA gene was statistically significant with presence iceA2 and cagA, as well as the presence ice $A$ gene was statistically significant with the presence vacA. There were 11 different genotype combinations and the most

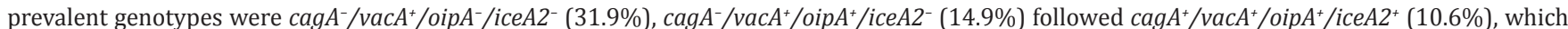
associated with severe pathologies than the first and the second type.

Conclusion: Most $H$. pylori genotypes which associated with peptic ulcer and gastritis were moderate virulent strains, whereas the virulent strain which associated with peptic ulcer belong to Western cagA strains had vacAs $1 \mathrm{bm} 2$ genotype, oipA and iceA2 genes that rarely induced gastric cancer in the middle region of Iraq.

Keywords: Helicobacter pylori, Gastric biopsies, Virulence genotyping, Cytotoxin-associated gene A, Vacuolating cytotoxin A, oipA, iceA.

(C) 2016 The Authors. Published by Innovare Academic Sciences Pvt Ltd. This is an open access article under the CC BY license (http://creativecommons. org/licenses/by/4. 0/) DOI: http://dx.doi.org/10.22159/ajpcr.2016.v9i6.13795

\section{INTRODUCTION}

Helicobacter pylori causes severe disease such as corpus gastritis, gastric atrophy, gastric ulcer, and increased risk of gastric cancer or gastric mucosa-associated lymphoid tissue lymphoma, in addition to developing a duodenal ulcer after gastric mucosa colonization [1] The clinical outcome of this infection associated with many factors like host genetic factors, environmental factors and virulence factors of H. pylori which diverse according to geographical area and a vital role in bacterial pathogenicity. Some of these virulence factors are encoded by cytotoxin-associated gene A $(\operatorname{cag} A), v a c A, i c e A$, and outer inflammatory protein A (oipA) genes [2,3].

Molecular methods are widely used to diagnose $H$. pylori infections as well as for analyses of virulence diversity and resistance patterns of these bacterial strains $[4,5]$. However, the high degree of genomic plasticity among strains of $H$. pylori caused the complexity of choosing the target genes. Even nucleotide sequences that are highly conserved in various strains of the pathogen, such as urease A (ureA), urease $C(g \operatorname{lm} M)$ and $16 S$ rRNA, may fail to detect the bacteria $[4,6]$ Therefore, another virulence genes can be detected as vacA, cagA genes to confirm the presence of virulent $H$. pylori strains $[3,7]$.

H. pylori produce large amounts of urease, an enzyme that hydrolyzes urea into ammonia and carbonates this mechanism to protect itself from acute acid shocks when it colonizes at gastric epithelial cells because of $H$. pylori is not an acidophil [8]. Urease enzyme encoded by ure operon that containing three clusters of genes, one of them is ureA which was used in bacterium molecular diagnosis. Furthermore, the bacterium has another gene (glmM or ureC) located upstream of the ure operon, but this gene does not participate in urease production, it encodes phosphoglucose amine mutase and it participates directly in cell wall synthesis. So both ureA and ureC considered "housekeeping" genes. However, they have been extensively used for confirming the presence of $H$. pylori $[9,10]$.

Furthermore, $H$. pylori possess various virulence factors as the cytotoxin-associated gene $\mathrm{A}(\operatorname{cag} A)$ and the vacuolating cytotoxin $(v a c A)$ that has been implicated in more severe responses within the host tissue. CagA is a cytotoxin that is translocated into host cells by the cag Type IV secretion system (cag-T4SS), encoded by several genes within the cag pathogenicity island (cag-PAI) [11]. CagA in either its phosphorylated form or its nonphosphorylated form can interact with at least 10 host cell components, resulting a complex assortment of cellular modifications. The level of CagA tyrosine phosphorylation in host cells is influenced by the number of EPIYA motifs within the protein that can undergo phosphorylation. $\operatorname{CagA}$ proteins containing higher numbers of EPIYA motifs exhibit enhanced binding to intracellular targets and enhanced activity within host cells, and strains have higher numbers of EPIYA motifs are related to greater gastric cancer 
risk [11,12]. CagA associated with different changes to gastric tissue, including upregulation of proinflammatory cytokines, alteration of the actin cytoskeleton, disruption of metal homeostasis, and aberrant cell signaling [12]. VacA is a pore-forming toxin encoded by vacA gene and secreted by $H$. pylori that cause cell vacuolation, autophagy, inhibition of T-cell proliferation, and induction of programmed necrosis $[7,12]$. As vacA gene show polymorphism among strains since it has four regions: A signal sequence consisting of the allele $\mathrm{s} 1$, which has three subtypes: s1a, s1b, s1c and s2; an intermediate sequence; a deleted sequence (d); and a middle sequence that may have the $\mathrm{m} 1$ or $\mathrm{m} 2$ alleles $[7,13,14]$. The mosaic combination of $\mathrm{s}$ and $\mathrm{m}$-region allelic types determines the particular cytotoxic and, consequently, the pathogenicity of the strain $[7,14]$. The most virulent strain is an $\mathrm{s} 1 \mathrm{~m} 1$ variant that produces a high level of cytotoxicity and associated with disease duodenal ulcer, the peptic ulcer disease (PUD) and gastric cancer as well as precancerous lesions and intestinal metaplasia, in addition to a wide variety of alterations in host cell biology $[12,15]$.

The induced by contact with the epithelium A gene (iceA) has two main allelic variants, iceA1, and iceA2. The iceA1 allele demonstrated sequence homology with a gene from Neisseria lactamica, nla IIIR, which encodes a cancer testis antigens-specific restriction endonuclease, but the similarity at the protein level is limited, due to frame shift mutations of iceA1 in most $H$. pylori strains [16]. Shiota et al. reported that the meta-analysis confirmed there was a significant association between the presence of the iceA1 allele and peptic ulcer, but there was inversely associated with the presence of iceA2 and peptic ulcer, as well as iceA gene was not associated with gastric cancer. Furthermore, they reported that there was no correlation between the presence of $\mathrm{cagA}$ and iceA1 allele [17]. The expression of iceA1 was upregulated on contact between H. pylori and human epithelial cells, and the iceA1 genotype was linked with enhanced mucosal interleukin (IL-8) expression and acute antral inflammation $[17,18]$.

Outer inflammatory protein A encoded by the oipA (hopH) gene and this gene may be functional or nonfunctional (status "on" or "off") depending on a variable number of cytosine-thymine dinucleotide repeats in the $5^{\prime}$ region of oipA $[2,19,20]$. The presence of a functional gene is significantly associated with the presence of duodenal ulcers, gastric cancer, and increased neutrophil infiltration. OipA expression is linked to increased IL-8 production in vitro; moreover, there is a strong link between the OipA "on"-status and cagA [19-21].

However, the main objective of researcher attention has more than one aspects including antimicrobial resistance properties of $H$. pylori and investigate new drug to treat infections $[3,15,22,23]$, molecular diagnosis or molecular analysis to investigate its role in gastric cancer $[2,7,15]$. In Iraq, H. pylori infections were diagnosed according to classical methods such as enzyme-linked immunosorbent assay, rapid chromatography strip assay, and rapid urease test where were performed at hospitals and the histological identifications were performed at private laboratories. To develop and applied the molecular diagnosis methods in Iraqi Hospitals, the recent researches scope of this field to construct a molecular database for local microbial species like H. pylori. In our previous studies (2012), H. pylori was isolated from antrum biopsies of patients suffering from various gastroduodenal diseases and identified according to classical methods, microbial, immunological and biochemical characteristics, in addition, to detecting $\operatorname{cag} A$ and $v a c A$ genes by polymerase chain reaction (PCR) using specific primers. The results of classical diagnosis appeared that $85.3 \%$ of patients had an immune response (specific antibodies) against $H$. pylori, and the percentage of isolation was $41.3 \%$ of peptic biopsies and depending on the PCR results were expected that these isolates related western isolates, as well as the studies, deal with antimicrobial resistance properties of $H$. pylori their association with plasmid profiles [24,25]. Whereas in 2015 H. pylori was detected directly in peptic biopsies of patients with gastritis and peptic ulcer using specific primers for ureC, ure $A$ and
16SrRNA genes by PCR [24] and the results appeared $65.3 \%$ cases were positive for $H$. pylori in addition to it was more reliable and requiring short time for diagnosis in comparison with the classical identification methods. To determine the genotype of local H. pylori strains that contributed gastroduodenal disease in the middle region of Iraq, the main objective of this study to investigate allelic polymorphism of vacA gene as well as cagA integrity and detection other virulence genes, also detect the association of these genes with gastric disease's outcome. The next study determines the sequences of virulent genes to predicate the more specific primer to detect local H. pylori strains.

\section{METHODS}

\section{Specimens sampling}

This study was performed in Biotechnology and Genetic Engineering Laboratory at Biology Department, College of Science, Babylon University in Iraq. Endoscopy was performed by a gastroenterologist at esophagi-gastroduodenal scope (OGD) unit at Morgan Hospital in Babylon Province. During the endoscopy, three biopsies were taken from the antrum, from February to May 2015. One of the antrum biopsies was used for rapid urease test at the hospital; two biopsies were used for genomic DNA extraction. Antrum biopsies were taken from 75 patients with dyspeptic symptoms including 38 gastritis, 28 PUD, 3 nodular growth non-malignant, and 6 were apparently normal. They attended service arguing dyspepsia, reflux, dysphagia, weight loss, anemia, and other symptoms; all of them met the inclusion criteria who were selected and identified by a specialist physician. The antrum biopsies were placed in sterile normal saline, transported to the laboratory using the cooling box, then frozen at $-24^{\circ} \mathrm{C}$ until processing.

\section{Genomic DNA extraction and purification}

The frozen biopsy specimens were thawed and crushed and genomic DNA was directly extracted and purified using FAVORGEN tissue genomic DNA extraction mini kit, according to the manufacturer's instructions. DNA quantity and quality were determined using an ultraviolet-visible Spectrophotometer-NanoDrop instrument (OPTIZEN POP - Korea). The concentration of DNA was measured at $260 \mathrm{~nm}$ which ranged $0.1-1.0 \mathrm{ng} / \mathrm{ml}$ and the DNA purity ranged between 1.7 and 2.0

\section{PCR amplification and electrophoresis}

For $H$. pylori genotyping, the target DNA regions were amplified using specific primers were mentioned in Table 1 . The reaction mixtures were prepared using a PCR Master Mix (Promega-USA) according to kit instructions. Each PCR reaction was carried out in a final volume of $25 \mu \mathrm{l}$ under different conditions were displayed in Table 1. We used a TRIO Thermal Cycler (Biometra-Germany) for gDNA amplification. PCR products were migrated and visualized in $1.5 \%$ $(\mathrm{w} / \mathrm{v})$ agarose gel electrophoresis in $1 \mathrm{X}$ of TAE buffer (Tris AcetateEthylenediaminetetraacetic acid buffer) composing from $0.040 \mathrm{~mol}$ Tris-acetate and $0.001 \mathrm{~mol}$ EDTA per L, pH $8.0 \pm 0.2$., at $6 \mathrm{~V} / \mathrm{cm}$ for $1 \mathrm{hr}$. Gels were stained with ethidium bromide solution $(5 \mu \mathrm{g} / \mathrm{ml})[26,27]$ using horizontal electrophoresis (Cleaver Scientific, UK) and Gel Documentation System (UVsolo touch, Biometra-Germany).

\section{Data analysis}

Data were analyzed using SPSS version 22 software Fisher's exact and Chi-square tests were used for analysis of cross table data, with a significant $p<0.05$ and correlation one-tail between genes and clinical outcome, with a significant $\mathrm{p}<0.05$ and $<0.01$. Genotypes with mixed status for vacA were excluded from the calculations of association.

\section{RESULTS AND DISCUSSION}

A total of 75 patients included in this study and have presented functional dyspepsia and/or chronic gastritis without atrophy or intestinal metaplasia. In the previous investigation, the presence 


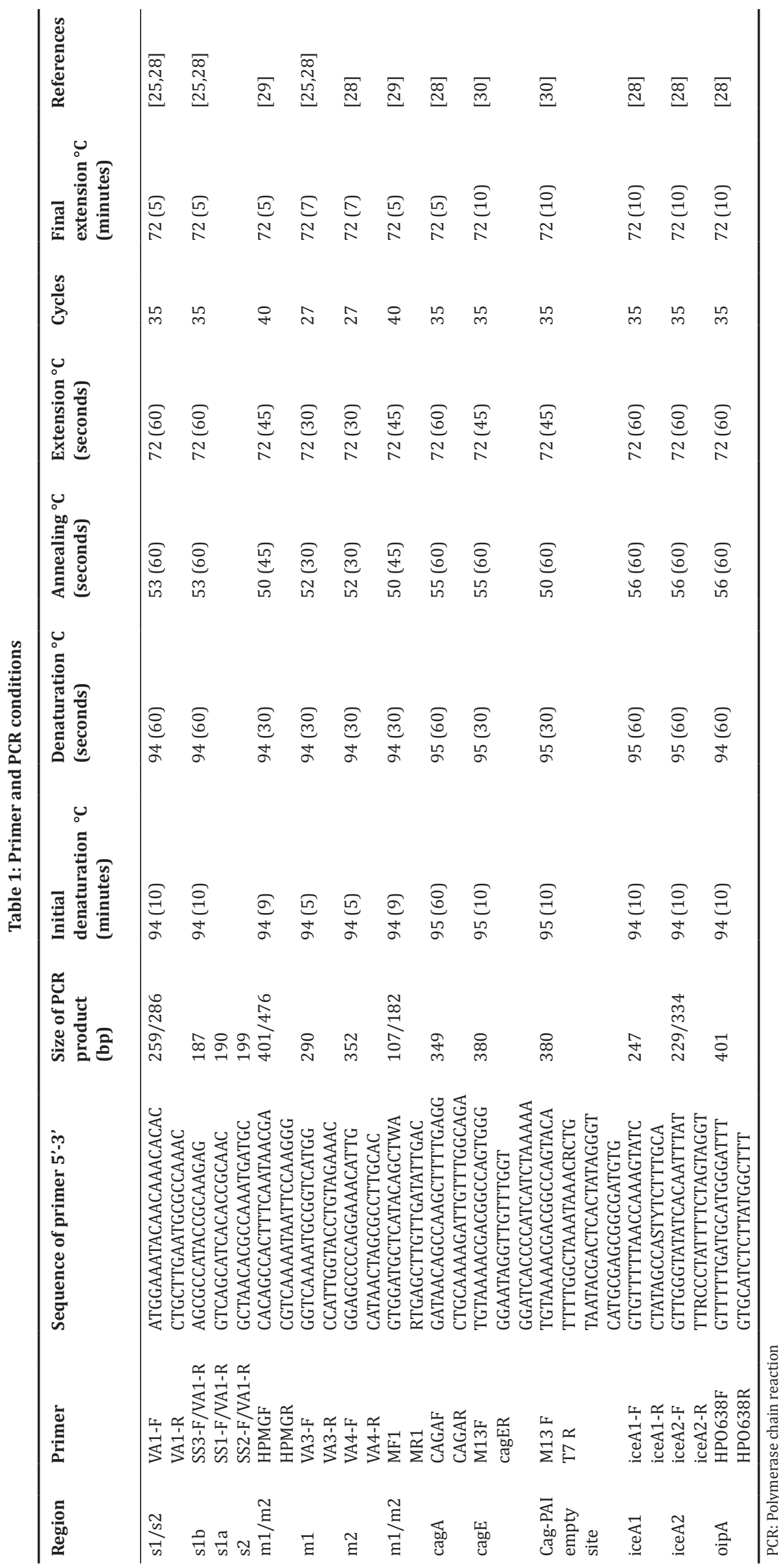


of $H$. pylori infections was confirmed by PCR analysis using specific primers for $16 \operatorname{SrRNA}$, ureC, and ureA genes. The identification results showed $49(65.3 \%)$ out of 75 biopsies gave positive results for at least two genetic markers including gastritis (55.26\%) and PUD (100\%) infections, but not the others [28]. Therefore, the total specimens harboring $H$. pylori which enrolled in this study were 49 cases.

The gDNA of the studied cases were analyzed for vacA and iceA allelic variant detection and $\operatorname{cag} A$ and oip $A$ genotyping using specific primers by PCR technique.

\section{vacA genotyping}

The results of vacA genotyping revealed that $42(85.71 \%)$ out of 49 cases were harboring $v a c A$ gene, which composed of single and middle regions including $\mathrm{s} 1 \mathrm{~m} 1, \mathrm{~s} 1 \mathrm{~m} 2$ or $\mathrm{s} 2 \mathrm{~m} 2$ allelotypes, but the allelotype s $2 \mathrm{~m} 1$ were not found. Two cases of them had two types of s-region (s1 and s2) as well as m-region (m1 and $\mathrm{m} 2$ ), so they were excluded from the calculations of association, that may indicate these patients had multiple infections by two different $H$. pylori strains. The rest cases $(12.24 \%)$ gave a negative result for the presence of vacA gene. All the PCR results were repeated more than three times using the primer pairs to amplify vacA s-region, including VA1F/VA1R and SS2-F/VA1R which resulted 259/286 bp for s1/s2 and 199 bp for s2 allelotypes, as well as vacA m-region was amplified using primer pairs VA3 (290 pb) for $\mathrm{m} 1$ type and VA4 (352 pb) for $\mathrm{m} 2$ type or HPMG (401/476 pb) for $\mathrm{m} 1 / \mathrm{m} 2$ types (Fig. 1). Our finding of $\mathrm{s} 1$ allelotype was distributed as $89.3 \%$ and $42.1 \%$ for individuals with PUD and gastritis, respectively. These results confirmed previous studies $[26,27]$. Noticeable samples in our study with a nodular growth have no detected any genes for $H$. pylori. For s2 allelotype, the distribution was $10.7 \%$ for PUD and $21.1 \%$ for gastritis; in the current study, there is no significant between the manifestation of disease and single region of $\operatorname{vac} A$ gene.

The positive cases (40) had s1 type (70.22\%) or s2 type (14.89\%) and $\mathrm{m} 1$ allele $(12.77 \%)$ or $\mathrm{m} 2$ allele $(72.34 \%)$. The relationship between vacA allelotypes and clinical outcome revealed that s1 type was dominated by individuals with PUD (89.29\%) and followed gastritis (42.1\%), also $\mathrm{m} 2$ type was dominated by individuals with PUD (85.71\%) and followed gastritis (52.62\%). As a result of the allelotype vacAs1m2 combined with the PUD and gastritis infections as a percentage $75 \%$ and $31.57 \%$, respectively (Table 2).

The s1 allele of vacA gene consists from three subtypes are s1a, s1b, and s1c, in our study only s1a and s1b subtypes were investigated, but not an s1c subtype because of it is exclusively found in East-Asian isolates [31]. The positive results of s1 type within 32 cases were consisting from s1a (18.75\%), s1b (75\%) as shown in Table 2, whereas two cases $(6.25 \%)$ were negative for both s1a and s1b subtypes; that may be indicated they had the third subtype which was not investigated in the present study that it may be classified into s1c. We think our study of allelotyping of vacA gene investigation is the first study in the middle region of Iraq, which found the allelotype vacAs $1 \mathrm{bm} 2$ is the predominant allele $(44.68 \%)$ related to gastritis and peptic ulcer. The results may be indicated, these isolates produced moderate vacuolating toxin and had moderately virulent in gastritis infection and peptic ulceration. However, the presence vacA gene within these isolates was increasing the pathogenicity and it had a statistically positive correlation with the disease $(p=0.01$ at a level 0.05$)$.
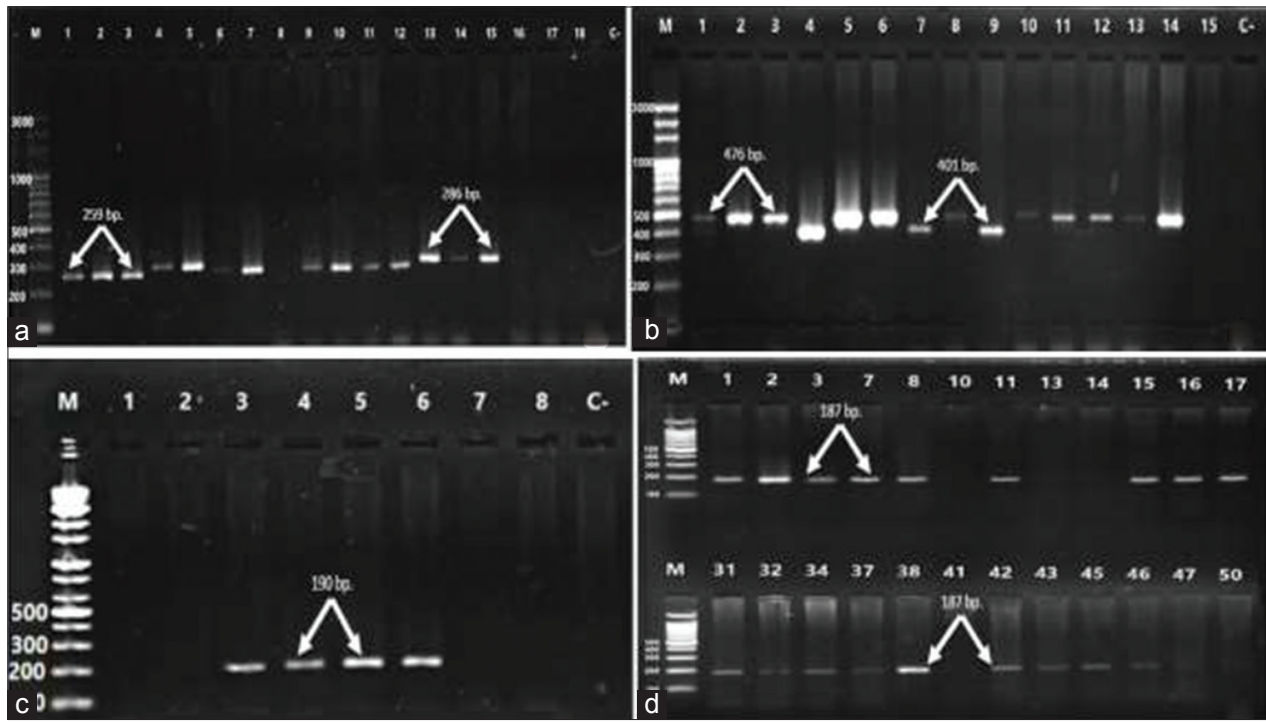

Fig. 1: Gel electrophoresis of polymerase chain reaction products of vacuolating cytotoxin A genotyping

Table 2: Relationship between vacA genotypes and manifestation of diseases

\begin{tabular}{lllll}
\hline Genotype & PUD N=28 (\%) & Gastritis N=19 (\%) & Total N=47 (\%) & p value (0.05) \\
\hline vacAs2m2 & $3(10.71)$ & $4(21.05)$ & $7(14.89)$ & 0.339 \\
vacAs1m1 & $4(14.29)$ & $2(10.53)$ & $6(12.77)$ & 0.712 \\
vacAs1m2 & $21(75)$ & $6(31.57)$ & $27(57.45)$ & 0.008 \\
Total & $28(100)$ & $12(63.16)$ & $40(85.11)$ & $0.01^{*}$ \\
s1-region subtype & $2(7.14)$ & 0 & $2(4.26)$ & 0.243 \\
vacAs1am1 & $3(10.71)$ & $1(5.26)$ & $4(8.51)$ & 0.522 \\
vacAs1am2 & $2(7.14)$ & $1(5.26)$ & $3(6.38)$ & 0.801 \\
vacAs1bm1 & $16(57.14)$ & $5(26.32)$ & $21(44.68)$ & 0.088 \\
vacAs1bm2 & $23(82.13)$ & $7(36.84)$ & $30(63.83)$ & \\
Total & & & \\
\hline
\end{tabular}

*vacA was statistically positively correlated with peptic ulcer and gastritis diseases. ( $\mathrm{P}=0.01$, significance level=0. 05) PUD: Peptic ulcer disease, VacA: Vacuolating cytotoxin A 
$1.5 \%$ agarose gel at $6 \mathrm{~V} / \mathrm{cm}$ for $1 \mathrm{hr}$; C: Negative control (Escherichia coli MM294), M: 100 bp DNA marker.

A. PCR product of s1 and s2 types $259 \mathrm{bp}$ and $286 \mathrm{bp}$, respectively; Lane 1 - 3, 6, 7, 10-12: Positive for s1 type, Lane 4, 5, 13-15: Positive for s2 type, mixed strain lane 9, other lanes were negative

B. PCR product of $\mathrm{m} 1$ and $\mathrm{m} 2$ type $401 \mathrm{bp}$ and $476 \mathrm{bp}$, respectively; Lane 4 7, 9: Positive for 1 type, Lane 2, 3, 5, 6, 8, 10-14: Show positive results of $\mathrm{m} 2$ type, Lane 1: Positive to both $\mathrm{m} 1$ and $\mathrm{m} 2$, Lane 15 was negative

C. PCR product of s1a subtype 190 bp; Lane 3, 4, 5, 6: Positive for s1a subtype, others were negative

D. PCR product of s1bsuballelic 187 bp; Lane 1-3, 7, 8, 11, 15-17, 31 , $32,34,37,38,42,43,45,46$ : Shows positive results for s1b subtype, other lanes were negative.

In comparison with the other studies that performed in the middle east region like Turkey and Egypt, which found vacAs1a allele is dominant (70.1\% and $72.5 \%$, respectively) than vacAs $1 b$ allele $(2.8 \%$ and $7.2 \%$, respectively) and $27.1 \%$ and $21.7 \%$, respectively, as vacA s2 $[32,33]$ The allelotype s1a is more active than s1b [29], and with other vacA genotypes, the combination is associated with greater pathogenicity and virulence related to gastric cancer and peptic ulceration $[34,35]$ Thus, the results of vacA s-region variation indicate that there is geographical variation within $H$. pylori strains. In comparison with other geographical regions the s1a alleles are predominantly in strains from northern and eastern Europe, whereas the s1b allelic types are common in such regions as Central and South America, Spain, Portugal, and South Africa. The s1b subtypes are rare in other regions and less virulent than other s1 subtypes [36,37]. The strains in the present study belong to western type, as studies indicated $\mathrm{s} 1 \mathrm{~b}$ subtype is rarely found in East-Asian countries [29,32,38]. Our results revealed $\mathrm{m} 2$ as the main allele that similar to studies from Iraq, Turkey, Iran, Saudi Arabia, and the middle east region characterized $\mathrm{m} 2$ as the main allele [14,32,33,39-42]. In another hand, some studies reported that the predominant vacA m subtype was $\mathrm{m} 2$ and no association or no role between $v a c A \mathrm{~m}$ genotypes and the development of peptic ulcer $[2,32,33,42,43]$, whereas other studies had been found that vacA $\mathrm{m} 1$ strains are associated with high levels of inflammation in the gastric mucosa and increased the risk of gastric atrophy and carcinoma $[2,44]$. However, the results were different from country to others, but we consistent with different studies those of Middle Eastern countries, in which the vacA $\mathrm{s} 1$ and $\mathrm{m} 2$ subtypes have been predominant subtypes $[32,42,45,46]$.

Essentially, all strains possess the vacA gene, but not all secrete functional active VacA proteins (biologically active toxin) due to the variation of gene structure [2,7]. Reports in different geographic regions (Middle East, Africa, and Western) were demonstrated that individuals infected with $H$. pylori strains harboring vacA s1 allele have an increased risk of peptic ulcer or gastric cancer compared with individuals infected with strains had vacA s2 type $[2,41,47,48]$. Whereas $H$. pylori with s2 having minor cytotoxic activity than $\mathrm{s} 1[2,39,48]$. Moreover, $H$. pylori strains have diverse combinations of vacA $\mathrm{s}$ and $\mathrm{m}$ regions and each strain possesses a unique pattern according to these combinations level of virulence of $H$. pylori is evaluated. The differences in allelotyping of vacA gene allow for differences in vacuolating activities between strains, and encoding proteins with different cytotoxicity, so vacA s1/m1 strains produce proteins with the high level of cytotoxicity and induce high vacuolation in gastric mucosa, while $\mathrm{s} 1 / \mathrm{m} 2$ strains produce proteins have moderate level of action, and there is typically no vacuolating activity in $\mathrm{s} 2 / \mathrm{m} 2$ strains $[2,29]$. Furthermore, heterogeneity among $v a c A$ alleles may be an important factor in understanding variations in clinical manifestations among $H$. pylori-infected subjects.

\section{$\operatorname{cag} A$ genotyping}

$\operatorname{cag} A$ gene is encoded $\operatorname{cag} A$ protein, where CagA is another toxin that enables the bacteria to bring damage to the host cell. $H$. pylori strains possess $\operatorname{cag} A$ gene are more virulent and associated with increasing risk for developed PUD, atrophic gastritis, and gastric cancer, and there is a direct link between the presence of CagA and an increased cancer risk $[7,42]$. The results revealed 14 from 49 samples positives for cagA gene by using cagA primers with product size 349 bp (Fig. 2a), the percentage of $\operatorname{cagA}$ in our study was $28.6 \%$, as lower as percent how reported by Hussein et al. [49] were $71 \%$ of study samples where were performed in Iraq at the different region, Kurdistan. Thus, suggesting there is wide variation in Iraqi strains those from north to those from the middle and south region. Furthermore, our results were different with the other countries were found the prevalence for cagA status in middle eastern countries like Jordan 26.4\%, Saudi Arabia 52\%, Kuwait 41\%, Iran 76\%, Turkey 78\%, Egypt 35.7\% [32,42,50]. Whereas East Asian, Western European, Latin American, Tunisian, and Lebanese strains have been revealed to have cagA positivity of nearly $100 \%, 80 \%$ $70 \%, 61.6 \%$, and $37.5 \%$, respectively [30,51-53].

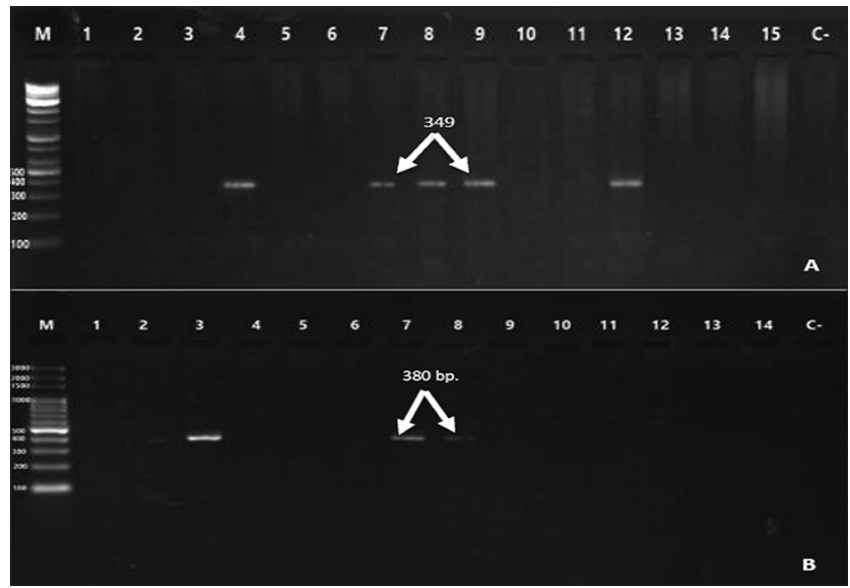

Fig. 2: Gel electrophoresis of polymerase chain reaction product of cytotoxin-associated geneA

$1.5 \%$ agarose gel at $6 \mathrm{~V} / \mathrm{cm}$ for $1 \mathrm{hr}$.

A. Gel electrophoresis of PCR product of cagA gene $349 \mathrm{bp}$ Lane 4, 7, 8, 9, 12: Positive for cagA gene, Lane 1-3, 5, 6, 10, 11, 13-15 negative results, C: Negative control (E. coli MM294, M 100 bp DNA marker)

B. Gel electrophoresis of PCR product of cagE gene $380 \mathrm{bp}$. Lane 3, 7, 8: Positive for cagE gene, Lane 1, 2, 4, 5, 6, 9, 10-14 negative results, C: Negative control (without DNA), M: $100 \mathrm{bp}$ DNA marker.

However, the results show there was a significant relationship between the presence of $c a g A$ and peptic ulceration $\mathrm{p} \leq 0.001$; the significant association confirmed by previous reports from Iraq and Turkey $[49,50]$ but the presence of $\operatorname{cagA}$ was higher than our finding this may be due to a regional area of research. Other middle eastern countries had been no significant between cagA status and incidence of diseases such as Turkey, Egypt, and Iran [30,32,39,42].

Table 3: $\operatorname{cagA}$ status with vacA polymorphisms of $H$. pylori

\begin{tabular}{llll}
\hline Combination vacA gene & $\boldsymbol{c a g}^{+} \mathbf{N}(\%)$ & $\boldsymbol{c a g A}^{-} \mathbf{N}(\%)$ & Total N (\%) \\
\hline vacAs1m1 & $4(28.6)^{*}$ & $2(6.1)$ & $6(12.77)$ \\
vacAs1m2 & $7(50)$ & $20(63.6)$ & $27(59.57)$ \\
vacAs2m2 & 0 & $7(21.2)$ & $7(14.89)$ \\
vacA & $3(21.4)$ & $4(9.1)$ & $7(12.7)$ \\
Total & $14(29.8)$ & $33(70.2)$ & $47(100)$ \\
vacAs1 subellelic & & & \\
s1am1 & $2(14.3)$ & 0 & $2(4.1)$ \\
s1am2 & 0 & $4(12.12)$ & $4(8.2)$ \\
s1bm1 & $2(14.3)$ & $1(3.03)$ & $3(6.1)$ \\
s1bm2 & $7(50)$ & $15(45.45)$ & $22(42.9)$ \\
Total & $11(78.6)$ & $20(60.6)$ & $31(87.23)$ \\
\hline
\end{tabular}

*Statistically significant $\mathrm{p}=0.04$ (significance level $=0.05$ ). $c a g A^{+}$: The isolates harboring the $\operatorname{cagA}$ gene, $\operatorname{cag} A^{-}$: The gene not found, H. pylori: Helicobacter pylori, VacA: Vacuolating cytotoxin A 
Among cagA positive strains, the most predominant vacA patterns in our study as shown in Table 3 were s1bm2 (50\%), interestingly, cagA positive strains statistically correlated with $\mathrm{s} 1 \mathrm{~m} 1$ pattern $\mathrm{p}=0.04$, odds ratio 6.60 (confidence interval 95\% 1.05; 41.51), but not to others, $\mathrm{p}>0.05$ for all others patterns. A study by Honarmand-Jahromy et al. [39] was performed in Tehran, Iran, whom found the vacA $\operatorname{sim} 2 \mathrm{cagA}{ }^{+}$ genotype was the most prevalent within the three disease groups including chronic gastritis, gastric ulcer and duodenal ulcer patients. In addition to the vacAs $1 \mathrm{~m} 2$ genotype was predominant with $56.2 \%$ with a similar occurrence in all diagnoses, while vacA $\mathrm{s} 1 \mathrm{~m} 1$ most prevalent within duodenal ulcer patients (33.9\%). Also, they found the genotype of vacA s $2 \mathrm{~m} 2$ occurred in $15 \%$ of isolates and was more common in chronic gastritis patients $(21.2 \%)$; vacA s $2 \mathrm{~m} 1$ were the least common genotype.

cag-PAI is a major virulence factor associated with several gastroduodenal pathologies, to test the integrity cag pathogenicity island, we had test presence of the $\operatorname{cag} E$ gene. This gene belongs to the cag pathogenicity island and locates in the upstream region of the island, cagE encodes a protein that caused induction of IL-8, and also this protein is a part of $H$. pylori cag T4SS apparatus [11,54]. As reports suggested that this gene is a more accurate marker of an intact pathogenicity island and can be used as a cag-PAI marker with cagA [55]. The results appeared $4(28.6 \%)$ out of 14 (positive cagA) samples have $\operatorname{cag} E$ (Fig. 2b) using specific primer for this region, amplification of cagE gene indicates these samples possess complete cag PAI, others samples that not yield, consider contain modified cag-PAI as well as might be lack cagE genotype. Moreover, another test was done by PCR assay using specific primer for the cag empty site to assess or confirm the loss of cag-PAI, the investigated amplicon for the empty site is about $380 \mathrm{bp}$, the results revealed six samples of not cagA positive have been lost cag PAI by giving $380 \mathrm{bp}$ size amplicon. Suggesting these samples infected with $H$. pylori strains undergo deletion to cag PAI and it's completely absent, among others cagA negative did not give any amplicon, so it still contains a partial cag PAI. However, the 14 samples that possessed $\operatorname{cag} A$ positive strains did not yield any empty site amplicon of the expected size, thus the result confirms those samples have $\operatorname{cag} A$ genotype and as a consequence, cag PAI was existing.

Jones et al. [56] reported that the presence of the cagA gene did not strictly correlate with expression and delivery of CagA in all noncancerous strains. This supports the idea of presence modification in $c a g$ PAI or lack cagE genotype as a protein of this gene is a part of H. pylori cag T4SS apparatus and mediate transport cagA protein to host cells [11,54]. Furthermore, Monstein et al. [57] suggesting the presence of a deviating cag-PAI. While Hussein et al. [49] found cagE in all $\operatorname{cagA} A^{+}$strains this contrary to our result.

The statistical analysis reveals a significant correlation between the presence of $\operatorname{cag} A$ and $\operatorname{cag} E$ genotypes ( $\mathrm{p}=0.02)$, suggesting that these two genes almost used together as a cag PAI integrity marker. Also, the presence of cagA and cagE increased the accuracy [54].

Also, the polymorphisms of cagA gene variable 3 ' end investigated by PCR, 14 samples with positive cagA gene had subjected to PCR using cagA-EPIYA primers to amplified cagA EPIYA motif region as previously described by Monstein et al. [57]. The amplicons ranged in size between $\sim 600$ and $\sim 900$ bp using single pair primer to produce varying PCR amplicons size depending on number of $\operatorname{cag} A$ EPIYA motifs. The results appeared the presence of variable amplicons in different biopsies, where 5 samples give PCR product of $\sim 650 \mathrm{bp}$; we expected the type of EPIYA in these samples is $\mathrm{ABC}$ and two samples give amplicon $\sim 580 \mathrm{bp}$ probably EPIYA type here $\mathrm{AB}$ or $\mathrm{BC}$, this primer pair enable to detect EPIYA types based on size, in which EPIYA-ABC give $~ 650$ bp EPIYA-C segment may multiplies variable, mostly from one time to three times, and give larger product size in EPIYA-ABCC or ABCCC 850-900 bp among different Western CagA species, in our results not revealed predicting size for EPIYA-ABCC or ABCCC. While other $\operatorname{cagA}$ positive samples, we did not detect any EPIYA (From 7 biopsy DNA samples, no $\operatorname{cag} A$ EPIYA motif amplicons could be generated). In conclusion, the predominant cagA EPIYA motif was ABC with the size of $\sim 650$ bp and belongs to Western cagA strains, as EPIYA-C is predominantly found in strains from Western countries [7]. There are many evidence indicate that the risk of gastric cancer or premalignant lesions is higher in persons infected with cagA positive $H$. pylori strains than in persons infected with cagA negative strains $[11,12]$. The increased risk of gastric cancer observed with cagA-positive strains (which often contain the entire cag PAI) are attributed to the cellular effects of CagA, combined with an enhanced gastric mucosal inflammatory response [12].

\section{iceA genotyping}

This gene related to some gastrointestinal disease. The iceA gene contains two allelic variants iceA1 and iceA2 [45,58]. Analysis of iceA gene based on PCR assay using primers specific to sequence region of iceA gene, which give products of $247 \mathrm{bp}$ and/or 229/334 bp for iceA1 and iceA2 respectively, as shown in Fig. 3. The primers yield a fragment of 229 or $334 \mathrm{bp}$ depending on the presence of a repetitive sequence of 105 nucleotides codifying for 35 amino acids in some ice $A 2$ alleles.

Overall, iceA1 was not found in the present study of all 49 isolates and ice 2 2 was found in 16 strains $34 \%$ and it was distributed between the PUD and gastritis at the percentage $28.6 \%$ and $42.1 \%$, respectively, this revealed a new picture for iceA genotyping, the absence of iceA1 may reflect a greater geographic divergence among strains in the present study compared with other studies that $H$. pylori genotypes are not uniformly distributed worldwide. As previously reported that the iceA1 and the iceA2 genotypes were, respectively, isolated in $60.2 \%$ and in $16 \%$ of strains [30]. The iceA1 genotype associated with peptic ulceration in patients $[2,16,30,58]$. In our study, ice $A 2$ allele was considered predominant and there was no association between iceA2 and cagA status. While Ozbey and Aygun [58] found a significant association between iceA2 and the presence of cagA. The function of iceA2 is unknown. In this study, combination vacA/iceA2 and cagA/iceA2 analysis demonstrated that the vacA/iceA2 and cagA/iceA2 were more prevalent in PUD patients $(28.6 \%$ and $17.9 \%$, respectively) than in patients with gastritis alone $(21.1 \%$ and $10.5 \%$, respectively). Whereas combination vacAs1/iceA2 analysis demonstrated that the vacAs1/iceA2 was relatively more prevalent in PUD patients (17.9\%) than in patients with gastritis alone (15.8\%), may be due to there is no association between the size of the iceA2 amplicon and diseases. The numbers in this study were relatively small which limited statistical analysis. These results were different with Kidd et al. [59] results who they found combination vacAs1/iceA analysis demonstrated that the vacAs1/iceA2 was more prevalent in PUD patients $(53 \%)$ than in patients with gastritis alone (23\%), whom they found an amplicon size of this gene related to discriminate between the PUD and gastritis alone because of their finding about the presence a significant relationship between the cassette structure of iceA2 and expression in vivo; the induction of iceA may also contribute to disease outcome.

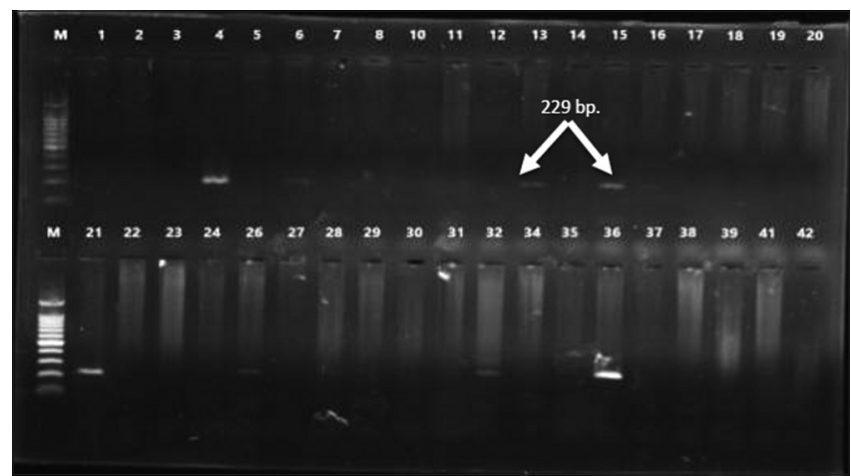

Fig. 3: Gel electrophoresis of polymerase chain reaction product of ice 2 allele $229 / 334 \mathrm{bp}$ 
$1.5 \%$ agarose gel at $6 \mathrm{~V} / \mathrm{cm}$ for $1 \mathrm{~h}$. Lane $4,6,13,15,21,26,32$, and 36 were positive for ice 2 allele, all other lanes were negative, M: 100-bp DNA marker.

\section{oipA genotyping}

The 5' region of the oipA gene was amplified using primers (HPO638F, HP0638R) to yield 401 bp PCR product (Fig. 4). The oipA genotype was detected in 21 (42.9\%) out of 49 strains, and the others were oipA negative; this result nearly consistent with the results of Yamaoka [60] who found the oipA gene in studied $H$. pylori isolates with the percentage $45.9 \%$ of strains, while it was less than the finding $(90.8 \%$ of strains) that documented by Ben Mansour et al. [30].

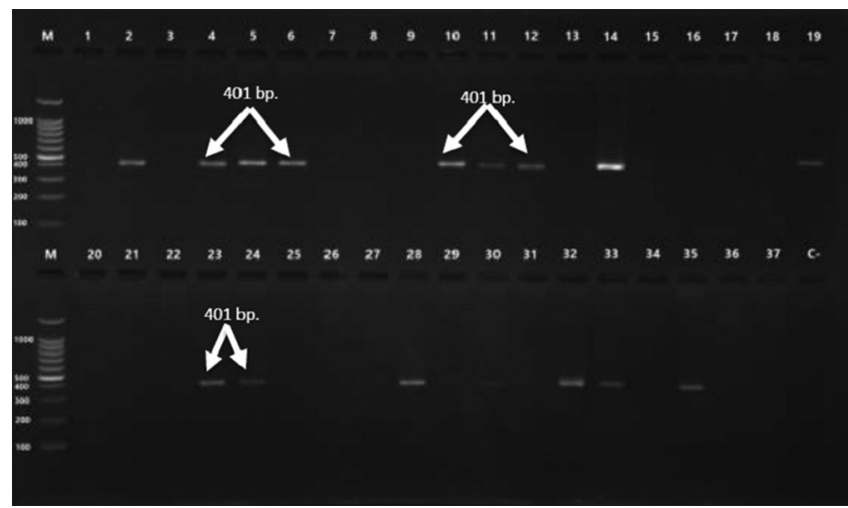

Fig. 4: Gel electrophoresis of polymerase chain reaction product of outer inflammatory protein A gene 401 bp

About $1.5 \%$ agarose gel at $6 \mathrm{~V} / \mathrm{cm}$ for $1 \mathrm{hr}$. Lane 2, 4-6, 10-12, 14, 19 $23,24,28,30,32,33$, and 35 were positive for oipA gene, Lane 1, 3, 7-9, $13,15-18,20-22,25-27,29,31,34,36$, and 37 show negative results, C: Negative control (E. coli MM294), M: 100-bp DNA marker.

The oipA (Hp0638) gene encodes an OipA, that associated with increased secretion of IL-8 $[2,3,13,19,61]$, our investigation reveals that patients with PUD more likely to have an oipA gene than those with gastritis with the percentage $61.9 \%$ and $38.1 \%$, respectively, with statistical significance $\mathrm{p} \leq 0.037$. Souod et al. [14] showed that there was no association between this gene and gastric disorders also they found in another study that the oipA gene was found in 88 (71.54\%) samples and statistically there was no association between this gene and gastric disorders [31]
Combined $\operatorname{cag} A$, vacA, iceA and oipA genotypes

In our study, first, we have studied the relationship between virulence genes (vacA, $\operatorname{cag} A, i c e A$, and oipA) and the different gastroduodenal diseases, between the two groups (patients with peptic ulceration/patients with gastritis) $v a c A^{+}$negatively correlated with gastritis, and positively correlated with PUD ( $\mathrm{p} \leq 0.001$ at a level 0.01 ), also $\mathrm{cagA}^{+}$negatively correlate with gastritis and positively correlated with PUD (significance 0.044 at the level 0.05 ). The combination of the distinct vacA, cagA, iceA, and oipA genotypes illustrated the mosaic composition of the $H$. pylori genome. Based on analysis of the $\operatorname{cag} A$ gene (positive and negative), the vacA s-region (s1 and s2), the iceA2 allelic type and the oipA gene (positive and negative), 11 different genotype combinations were recognized as shown in Table 4. The most prevalent

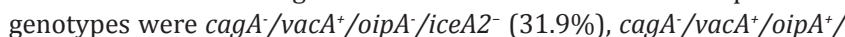
ice $A 2^{-}$(14.9\%) followed by cag $A^{+} /$vac $^{+} /$oip $A^{+} /$ice $A 2^{+}$(10.6\%), which associated with severe pathologies than the first and the second type. The first type was lower virulent than the second type as a result in most $H$. pylori strains that had been caused gastroduodenal diseases in middle Iraq are low virulence.

The overall results, we have examined the prevalence of vacA, cagA, iceA, and oipA genotypes of $H$. pylori strains clinically isolated in Iraq. No significant correlation was found between the expression of cagA and iceA2 genes and the two groups of study patients, but the difference was statistically significant between the vacA and oipA genes. Also, the results revealed that the presence of oip $A$ gene was correlated positively with the presence iceA2 gene $(\mathrm{p} \leq 0.024)$ and $\operatorname{cagA}^{+}(\mathrm{p} \leq 0.006$ at a level 0.01$)$, whereas iceA2 positively correlated with $v a c A$ at $(\mathrm{p} \leq 0.006$ at level 0.01).

Our different from Ben Mansour et al. [30] finding how reported the prevalence of the vacA, cagA, iceA and oipA genotypes of $H$. pylori strains clinically isolated from peptic ulcer and gastritis in Tunisia which typed as vacA $s 2 / \mathrm{cagA}^{+} / \mathrm{ice}^{+} / \mathrm{oipA}^{+}$were more prevalent than those typed as vacA s1/cag $A^{+} /$ice $^{+} /{ }^{+}$ip $A^{+}$and which are related to severe pathologies, and no significant correlation was found between the expression of $\operatorname{cag} A$ and iceA genes and the two groups of studied patients, but the difference was statistically significant with the $v a c A$ and oipA genes. Moreover, they suggested that vacA gene possibly works as an immune modulator changing the immune response to the immunogenic cagA. The cytoskeleton of gastric epithelial cells is disorganized by cagA, and $v a c A$, which leads to amplified cell spreading and growth. When $\operatorname{cag} A$ and $v a c A$ are combined, they can reduce the effect of each protein alone, probably leading to much more survival of infected host cells. This, possibly, occurs by ending vacA induced apoptosis or by inhibiting the vacA induced autophagy pathway by $\operatorname{cag} A[30]$.

Table 4: The genotype of $H$. pylori and their combination with PUDs and gastritis

\begin{tabular}{|c|c|c|c|c|}
\hline \multirow[t]{2}{*}{ H. pylori genotype } & \multirow{2}{*}{$\begin{array}{l}\text { Molecular identification }^{\mathrm{a}} \\
\text { ureC/16SrRNA/ureA }\end{array}$} & \multicolumn{3}{|l|}{ Disease } \\
\hline & & PUD N=28 (\%) & Gastritis $\mathrm{N}=19(\%)$ & Total $\mathrm{N}=47(\%)$ \\
\hline \multicolumn{5}{|l|}{$\operatorname{cagA}^{+}, \operatorname{vacA}^{+}$} \\
\hline $\operatorname{cag}^{+} /$vacA $^{+} /$oip $A^{+} /$iceA2 $^{+}$ & +++ & $5(17.9)$ & 0 & $5(10.6)$ \\
\hline $\operatorname{cag}^{+} / \mathrm{vacA}^{+} / \mathrm{oip}^{+} /$iceA2 $^{-}$ & +++ & $3(10.7)$ & 0 & $3(6.4)$ \\
\hline $\operatorname{cagA}^{+} / \mathrm{vacA}^{+} /$oipA $^{-} /$iceA2 $^{-}$ & -++ & $3(10.7)$ & 0 & $3(6.4)$ \\
\hline \multicolumn{5}{|l|}{$\operatorname{cag} A^{+}, v a c A^{-}$} \\
\hline $\operatorname{cag}^{+} /$vacA $^{-} /$oip $A^{-} /$iceA2 $^{+}$ & +++ & 0 & $2(10.5)$ & $2(4.2)$ \\
\hline $\operatorname{cag}^{+} /$vacA $^{-} /$oip $A^{-} /$iceA2 $2^{-}$ & -++ & 0 & $1(5.3)$ & $1(2.1)$ \\
\hline \multicolumn{5}{|l|}{$\operatorname{cag} A^{-}, v a c A^{+}$} \\
\hline $\operatorname{cag}^{-} / \operatorname{vac}^{+} /$oip $A^{+} /$ice $A 2^{+}$ & -++ & $3(10.7)$ & $2(10.5)$ & $5(10.6)$ \\
\hline $\operatorname{cagA}^{-} / \mathrm{vacA}^{+} /$oip $A+/$ iceA2- & -++ & $2(7.1)$ & $5(26.3)$ & 7 (14.9) \\
\hline $\operatorname{cagA}^{-} /$vacA $^{+} /$oipA $^{-} /$iceA2 $^{+}$ & +++ & 0 & $2(10.5)$ & $2(4.2)$ \\
\hline $\operatorname{cagA}^{-} /$vacA $^{+} /$oip $^{-} /$iceA2 $^{-}$ & -++ & $12(42.9)$ & $3(15.8)$ & $15(31.9)$ \\
\hline \multicolumn{5}{|l|}{$\operatorname{cagA} A^{-}, \operatorname{vacA}^{-}$} \\
\hline $\operatorname{cag}^{-} / \operatorname{vac}^{-} /$oip $A^{-} /$iceA2 $2^{-}$ & +++ & 0 & $2(10.5)$ & $2(4.2)$ \\
\hline $\operatorname{cag}^{-} /$vacA $^{-} /$oip $^{-} /$iceA2 $^{+}$ & +++ & 0 & $2(10.5)$ & $2(4.2)$ \\
\hline Total (\%) & & $28(59.6)$ & $19(40.4)$ & $47(100)$ \\
\hline
\end{tabular}

${ }^{a}$ The results are cited from our previous paper [24]. H. pylori: Helicobacter pylori, PUD: Peptic ulcer disease, VacA: Vacuolating cytotoxin A, OipA: Outer inflammatory protein A gene, CagA: Cytotoxin-associated gene A 


\section{CONCLUSIONS}

In general, these data support the hypothesis that there is a difference between bacterial strains associated with and without illness. The absolute separation is suggesting that other factors must play a role in the pathogenesis of the disease. Analysis of allelic types virulence genes useful in Iraq and may provide certain combinations of virulence factors are excellent positive or negative marks.

Most H. pylori genotypes which associated with peptic ulcer and gastritis were moderate virulent strains, whereas the virulent strain which associated with peptic ulcer belong to, Western $\operatorname{cagA}$ strains had vacAs1bm2 genotype, oipA and iceA2 genes which rarely induced gastric cancer in the middle region of Iraq. The cagA gene significantly associated with PUD, but it is not related with iceA. Both vacA and iceA related to oipA gene.

In Iraq, the H. pylori-associated diseases need further molecular studies for bacterial genotypes evaluation to clarifying their role in the clinical outcome and improve molecular diagnoses methods to prevent the bacterial infection risks.

\section{ACKNOWLEDGMENT}

The authors are thankful to College of Science, Babylon University and esophagi-gastroduodenal scope unit at Morgan Hospital in Babylon Province and the faculties for providing facilities needed for our work. We appreciate the agreements of patients and cooperation to provide the biopsies.

\section{REFERENCES}

1. Thorell K, Hosseini S, Palacios Gonzáles RV, Chaotham C, Graham DY, Paszat L, et al. Identification of a Latin American-specific BabA adhesin variant through whole genome sequencing of Helicobacter pylori patient isolates from Nicaragua. BMC Evol Biol 2016;16:53.

2. Kao CY, Sheu BS, Wu JJ. Helicobacter pylori infection: An overview of bacterial virulence factors and pathogenesis. Biomed $\mathrm{J}$ 2016;39(1):14-23.

3. Hemmatinezhad B, Momtaz H, Rahimi E. VacA, cagA, iceA and oipA genotypes status and antimicrobial resistance properties of Helicobacter pylori isolated from various types of ready to eat foods. Ann Clin Microbiol Antimicrob 2016;15:2.

4. Essawi T, Hammoudeh W, Sabri I, Sweidan W, Farraj MA. Determination of Helicobacter pylori virulence genes in gastric biopsies by PCR. ISRN Gastroenterol 2013;2013:606258.

5. Zhou J, Wang W, Xie Y, Zhao Y, Chen X, Xu W, et al. Proteomics - Based identification and analysis of proteins associated with Helicobacter pylori in gastric cancer. PLoS One 2016;11(1):e0146521.

6. Ganguly M, Sarkar S, Ghosh P, Sarkar A, Alam J, Karmakar BC, et al. Helicobacter pylori plasticity region genes are associated with the gastroduodenal diseases manifestation in India. Gut Pathog 2016;8:10.

7. da Costa DM, Pereira Edos S, Rabenhorst SH. What exists beyond cagA and vacA? Helicobacter pylori genes in gastric diseases. World J Gastroenterol 2015;21(37):10563-72.

8. Keilberg D, Ottemann KM. How Helicobacter pylori senses, targets and interacts with the gastric epithelium. Environ Microbiol 2016;18(3):791-806.

9. Espinoza MG, Vazquez RG, Mendez IM, Vargas CR, Cerezo SG. Detection of the glmM gene in Helicobacter pylori isolates with a novel primer by PCR. J Clin Microbiol 2011;49(4):1650-2.

10. Ramis IB, Vianna JS, Gonçalves CV, von Groll A, Dellagostin OA, da Silva PE. Polymorphisms of the IL-6, IL-8 and IL-10 genes and the risk of gastric pathology in patients infected with Helicobacter pylori. J Microbiol Immunol Infect 2015. pii: S1684-118200721-5.

11. Johnson EM, Gaddy JA, Voss BJ, Hennig EE, Cover TL. Genes required for assembly of pili associated with the Helicobacter pylori cag type IV secretion system. Infect Immun 2014;82(8):3457-70.

12. Haley KP, Gaddy JA. Helicobacter pylori: Genomic insight into the host-pathogen interaction. Int J Genomics 2015;2015:386905.

13. Pajavand H, Alvandi A, Mohajeri P, Bakhtyari S, Bashiri H, Kalali B, et al. High frequency of vacA $\mathrm{s} 1 \mathrm{~m} 2$ genotypes among Helicobacter pylori isolates from patients with gastroduodenal disorders in Kermanshah, Iran. Jundishapur J Microbiol 2015;8(11):e25425.

14. Souod N, Kargar M, Doosti A, Ranjbar R, Sarshar M. Genetic analysis of cagA and vacA genes in Helicobacter pylori isolates and their relationship with gastroduodenal diseases in the West of Iran. Iran Red Crescent Med J 2013;15(5):371-5.

15. Ashwini P, Sumana MN, Shilpa U, Mamatha P, Manasa P, Dhananjaya BL, et al. A review on Helicobacter pylori: Its biology, complications and management. Int J Pharm Pharm Sci 2015;7 Suppl 1:14-20.

16. Figueiredo C, Quint WG, Sanna R, Sablon E, Donahue JP, Xu Q, et al. Genetic organization and heterogeneity of the iceA locus of Helicobacter pylori. Gene 2000;246(1-2):59-68.

17. Shiota S, Watada M, Matsunari O, Iwatani S, Suzuki R, Yamaoka Y. Helicobacter pylori iceA, clinical outcomes, and correlation with cagA: A meta-analysis. PLoS One 2012;7(1):e30354

18. Shiota S, Suzuki R, Yamaoka Y. The significance of virulence factors in Helicobacter pylori. J Dig Dis 2013;14(7):341-9.

19. Liu J, He C, Chen M, Wang Z, Xing C, Yuan Y. Association of presence/ absence and on/off patterns of Helicobacter pylori oipA gene with peptic ulcer disease and gastric cancer risks: A meta-analysis. BMC Infect Dis 2013;13:555.

20. Oleastro M, Ménard A. The role of Helicobacter pylori outer membrane proteins in adherence and pathogenesis. Biology (Basel) 2013;2(3):1110-34.

21. Dossumbekova A, Prinz C, Mages J, Lang R, Kusters JG, Van Vliet AH, et al. Helicobacter pylori HopH (OipA) and bacterial pathogenicity: Genetic and functional genomic analysis of hopH gene polymorphisms. J Infect Dis 2006;194(10):1346-55.

22. Gehlot V, Mahant S, Das K, Das R. Most of the Helicobacter pylori isolates are resistant to levofloxacin in north India. Int J Pharm Pharm Sci 2016;8(1):454-56

23. Gehlot V, Mahant S, Vijayraghwan P, Das K, Hoda S, Das R. Therapeutic potential of lichen Parmelia perlata against daul drag - resistant Helicobacter pylori isolates. Int J Pharm Pharm Sci 2016;8(1):205-8.

24. Omran R, Al-Khafagee AH. Multiple resistance to antibiotics in Helicobacter pylori isolated from peptic and duodenal ulcers. J Babylon Univ 2013;21(6):2050-7.

25. Al-Khafagee AH. Genetic study of Helicobacter pylori. M.Sc. Thesis College of Science, Babylon University; 2012.

26. Sambrook J, Fritschi E, Maniatis T. Molecular Cloning: A Laboratory Manual. New York: Cold Spring Harbor Laboratory Press; 1989.

27. Omran R,Al-ZaagA. Ultrastructure and genetic analysis of mucogenicity in Klebseilla pneumoniae. Iraqi J Biotechnol 2005;4(2):85-98.

28. Al-Naji HA, Omran O, Al-Sherify A. Molecular detection of Helicobacter pylori infection in gastric biopsy specimens by PCR. J Babylon Univ 2016;25(3):1016-28.

29. Atherton JC, Cao P, Peek RM Jr, Tummuru MK, Blaser MJ, Cover TL. Mosaicism in vacuolating cytotoxin alleles of Helicobacter pylori. Association of specific vacA types with cytotoxin production and peptic ulceration. J Biol Chem 1995;270(30):17771-7.

30. Ben Mansour K, Fendri C, Zribi M, Masmoudi A, Labbene M, Fillali A, et al. Prevalence of Helicobacter pylori vacA, cagA, iceA and oipA genotypes in Tunisian patients. Ann Clin Microbiol Antimicrob 2010;9:10.

31. SouodN, SarsharM,DabiriH, MomtazH, KargarM, MohammadzadehA, et al. The study of the oipA and dupA genes in Helicobacter pylori strains and their relationship with different gastroduodenal diseases. Gastroenterol Hepatol Bed Bench 2015;8 Suppl 1:S47-53.

32. Erdogdu C, Saribas Z, Akyön Yilmaz Y. Detection of cagA and vacA genotypes of Helicobacter pylori isolates from a university hospital in Ankara region, Turkey. Turk J Med Sci 2014;44(1):126-32.

33. Amer FA, El-Sokkary RH, Elahmady M, Gheith1 T, Abdelbary EH, Elnagar Y, et al. Helicobacter pylori genotypes among patients in a university hospital in Egypt: Identifying the determinants of disease severity. J Microb Infect Dis 2013;3(3):109-15.

34. Yakoob J, Abid S, Abbas Z, Jafri W, Ahmad Z, Ahmed R, et al. Distribution of Helicobacter pylori virulence markers in patients with gastroduodenal diseases in Pakistan. BMC Gastroenterol 2009;9:87.

35. Aziz F, Chen X, Yang X, Yan Q. Prevalence and correlation with clinical diseases of Helicobacter pylori cagA and vacA genotype among gastric patients from Northeast China. Biomed Res Int 2014;2014:142980.

36. Yamazaki S, Yamakawa A, Okuda T, Ohtani M, Suto H, Ito Y, et al. Distinct diversity of vacA, cagA, and cagE genes of Helicobacter pylori associated with peptic ulcer in Japan. J Clin Microbiol 2005;43(8):3906-16.

37. Atherton JC. The pathogenesis of Helicobacter pylori-induced gastroduodenal diseases. Annu Rev Pathol 2006;1:63-96.

38. van Doorn LJ, Figueiredo C, Rossau R, Jannes G, van Asbroek M, Sousa JC, et al. Typing of Helicobacter pylori vacA gene and detection 
of cagA gene by PCR and reverse hybridization. J Clin Microbiol 1998;36(5):1271-6.

39. Honarmand-Jahromy S, Siavoshi F, Malekzadeh R, Nejad Sattari T, Latifi-Navid S. Reciprocal impact of host factors and Helicobacter pylori genotypes on gastric diseases. World J Gastroenterol 2015;21(31):9317-27.

40. Wong BC, Yin Y, Berg DE, Xia HH, Zhang JZ, Wang WH, et al. Distribution of distinct vacA, cagA and iceA alleles in Helicobacter pylori in Hong Kong. Helicobacter 2001;6(4):317-24.

41. Sugimoto M, Zali MR, Yamaoka Y. The association of vacA genotypes and Helicobacter pylori - Related gastroduodenal diseases in the Middle East. Eur J Clin Microbiol Infect Dis 2009;28(10):1227-36.

42. Hussein NR. Helicobacter pylori and gastric cancer in the Middle East: A new enigma? World J Gastroenterol 2010;16(26):3226-34.

43. Alikhani MY, Arebestani MR, Sayedin Khorasani M, Majlesi A, Jaefari M. Evaluation of Helicobacter pylori vacA and cagA genotypes and correlation with clinical outcome in patients with dyspepsia in hamadan province, Iran. Iran Red Crescent Med J 2014;16(11):e19173.

44. González CA, Figueiredo C, Lic CB, Ferreira RM, Pardo ML, Ruiz Liso JM, et al. Helicobacter pylori cagA and vacA genotypes as predictors of progression of gastric preneoplastic lesions: A longterm follow-up in a high-risk area in Spain. Am J Gastroenterol 2011;106(5):867-74.

45. Rhead JL, Letley DP, Mohammadi M, Hussein N, Mohagheghi MA, Hosseini ME, et al. A new Helicobacter pylori vacuolating cytotoxin determinant, the intermediate region, is associated with gastric cancer Gastroenterology 2007;133:926-36.

46. Salehi Z, Abadi AS, Ismail PB, Kqueen CY, Jelodar MH, Kamalidehghan B. Evaluation of Helicobacter pylori vacA genotypes in Iranian patients with peptic ulcer disease. Dig Dis Sci 2009;54(11):2399-403.

47. Sugimoto M, Yamaoka Y. The association of vacA genotype and Helicobacter pylori-related disease in Latin American and African populations. Clin Microbiol Infect 2009;15(9):835-42.

48. Duncan SS, Valk PL, McClain MS, Shaffer CL, Metcalf JA, Bordenstein SR, et al. Comparative genomic analysis of East Asian and non-Asian Helicobacter pylori strains identifies rapidly evolving genes. PLoS One 2013;8(1):e55120.

49. Hussein NR, Mohammadi M, Talebkhan Y, Doraghi M, Letley DP, Muhammad MK, et al. Differences in virulence markers between Helicobacter pylori strains from Iraq and those from Iran: Potential importance of regional differences in Helicobacter pylori - Associated disease. J Clin Microbiol 2008;46:1774-9.
50. Saribasak H, Salih BA, Yamaoka Y, Sander E. Analysis of Helicobacter pylori genotypes and correlation with clinical outcome in Turkey. J Clin Microbiol 2004;42(4):1648-51.

51. Chen XJ, Yan J, Shen YF. Dominant cagA/vacA genotypes and coinfection frequency of Helicobacter pylori in peptic ulcer or chronic gastritis patients in Zhejiang province and correlations among different genotypes, co-infection and severity of the diseases. Chin Med J (Engl) 2005;118(6):460-7.

52. Ghose C, Perez-Perez GI, van Doorn LJ, Domínguez-Bello MG, Blaser MJ. High frequency of gastric colonization with multiple Helicobacter pylori strains in Venezuelan subjects. J Clin Microbio 2005;43(6):2635-41.

53. Khayat AE, Soweid AM, Kattar MM, Tawil A, Gold B, Matar GM Prevalence and clinical relevance of Helicobacter pylori cagA and $v a c A$ genes in Lebanese patients with gastritis and peptic ulcer disease. J Infect Dev Countries 2007;1:55-61.

54. Rizzato C, Torres J, Plummer M, Muñoz N, Franceschi S Camorlinga-Ponce $\mathrm{M}$, et al. Variations in Helicobacter pylor cytotoxin-associated genes and their influence in progression to gastric cancer: Implications for prevention. PLoS One 2012;7(1):e29605.

55. Lima VP, Silva-Fernandes IJ, Alves MK, Rabenhorst SH. Prevalence of Helicobacter pylori genotypes (vacA, cagA, cagE and virB11) in gastric cancer in Brazilian's patients: An association with histopathological parameters. Cancer Epidemiol 2011;35(5):e32-7.

56. Jones KR, Joo YM, Jang S, Yoo YJ, Lee HS, Chung IS, et al. Polymorphism in the CagA EPIYA motif impacts development of gastric cancer. J Clin Microbiol 2009;47(4):959-68.

57. Monstein HJ, Karlsson A, Ryberg A, Borch K. Application of PCR amplicon sequencing using a single primer pair in PCR amplification to assess variations in Helicobacter pylori CagA EPIYA tyrosine phosphorylation motifs. BMC Res Notes 2010;3:35.

58. Ozbey G, Aygun C. Prevalence of genotypes in Helicobacter pylor isolates from patients in eastern Turkey and the association of these genotypes with clinical outcome. Braz J Microbiol 2012;43(4):1332-9.

59. Kidd M, Peek RM, Lastovica AJ, Israel DA, Kummer AF, Louw JA. Analysis of iceA genotypes in South African Helicobacter pylori strains and relationship to clinically significant disease. Gut 2001;49:629-35.

60. Yamaoka Y. Mechanisms of disease: Helicobacter pylori virulence factors. Nat Rev Gastroenterol Hepatol 2010;7(11):629-41.

61. Zhong Y, Anderl F, Kruse T, Schindele F, Jagusztyn-Krynicka EK, Fischer W, et al. Helicobacter pylori HP0231 influences bacterial virulence and Is essential for gastric colonization. PLoS One 2016;11(5):e0154643 